\title{
Integrated Control of Root and Crown Rot in Sugar Beet: Combined Effects of Cultivar, Crop Rotation, and Soil Tillage
}

Cord Buhre and Christian Kluth, Institute of Sugar Beet Research, Holtenser Landstr. 77, 37079 Göttingen, Germany; Klaus Bürcky, Kuratorium für Versuchswesen und Beratung im Zuckerrübenanbau, Marktbreiter Straße 74, 97199 Ochsenfurt, Germany; and Bernward Märländer and Mark Varrelmann, Institute of Sugar Beet Research, Göttingen, Germany

\begin{abstract}
Buhre, C., Kluth, C., Bürcky, K., Märländer, B., and Varrelmann, M. 2009. Integrated control of root and crown rot in sugar beet: Combined effects of cultivar, crop rotation, and soil tillage. Plant Dis. 93:155-161.

Rhizoctonia solani (AG 2-2IIIB), causing root and crown rot in sugar beet, poses an increasing problem in Europe. Agronomic measures have to be optimized to control disease and minimize yield and quality loss, because no fungicides can be applied. Resistant sugar beet cultivars have been introduced to reduce disease occurrence. Furthermore, crop rotation can influence $R$. solani occurrence. In contrast to other cereals, maize serves as a host of the fungus. In order to study the combined effect of these factors, a series of four field trials was established with crop rotations varying in the proportion of maize and comparing a resistant with a susceptible sugar beet cultivar in 2001-02 in southern Germany. Within crop rotations, cultivation methods were varied in the form of soil tillage, intercrops, or both. Sugar beet cultivar and crop rotation had the main impact on disease severity and sugar yield. With increasing proportion of maize, sugar yield decreased, whereas cultivation method had only a minor impact. Plowing directly before sugar beet increased sugar yield only within the unfavorable maize-maize-sugar beet rotation compared with mulching. These results give strong evidence that crop rotation of sugar beet with nonhost plants and cultivation of resistant sugar beet cultivars are adequate means for integrated R. solani control.
\end{abstract}

Additional keyword: corn

Root and crown rot, caused by Rhizoctonia solani (Kühn), is an increasing problem for sugar beet cultivation in Europe and several other countries, such as the United States. In Europe, approximately 36,000 ha are affected (2).

Following current systematics, $R$. solani is a heterogeneous basidiomycete species and can be divided into 13 different anastomosis groups (AGs) $(9,10,31)$. AG 2-2 causes Rhizoctonia root and crown rot in sugar beet (21). In Germany and other European countries, the main subgroup isolated from sugar beet was AG 2-2IIIB (7). In the United States, both subgroups of AG 2-2 (IIIB and IV) have been demonstrated to cause root and crown rot (11). Serious yield decline and up to $60 \%$ plant losses can be observed in diseased fields in the United States (1). However, the disease appears in patches and the severity varies enormously from field to field and within disease patches (21). In Europe, similar yield losses can occur (7) and the decreas-

Corresponding author: Mark Varrelmann

E-mail: varrelmann@ifz-goettingen.de

Accepted for publication 15 October 2008.

doi:10.1094/PDIS-93-2-0155

(C) 2009 The American Phytopathological Society ing quality of infested sugar beet plants increases technical problems during sugar refinery (3).

In Europe, the disease control of $R$. solani in sugar beet with fungicides is not feasible because no agent is registered. Furthermore, control by antagonists is not yet available for agricultural practice. Therefore, an integrated approach has to focus on other possible control strategies. In 2001, resistant sugar beet cultivars were introduced in Europe to reduce disease occurrence and stabilize yield in infested fields (7). These cultivars have mainly been developed from germplasm released by the United States Department of Agriculture $(15,32)$. Resistance against $R$. solani is described to be quantitative, based on at least two loci with a probable involvement of further minor and modifying genes $(18,32)$. The resistance cannot entirely inhibit infection but limits and decelerates fungal colonization of the root tissue (39). Unfortunately, resistant cultivars still show some yield penalty under nondiseased conditions compared with susceptible cultivars and show higher susceptibility to bolting (7). These cultivars were tested for resistance and performance in special resistance trials. However, the relevance of the resistance in combination with other agronomical means for the natural infestation level of fields has not been studied to date.
A further promising approach to control the disease is the design of crop rotations because various other crops (e.g., bean and maize) are identified as host plants for $\mathrm{AG}$ 2-2IIIB and 2-2IV $(11,26,30,47)$. As precrop, host plants such as sorghum, soybean, other bean species, and maize increase disease severity in sugar beet $(43,51)$. In the United States, dry bean species are often grown in rotation with sugar beet and, therefore, it has been concluded that close rotations of host plants should be avoided (11). Negative effects from short crop rotations have been shown for a series of $R$. solani host plants; for example, potato $(16,25,35)$, wheat $(44)$, and sugar beet (45). However, crop rotation experiments did not consistently show the expected relationship of disease severity and precrop susceptibility (e.g., maize; 48). For sugar beet, the main factor influencing disease occurrence and severity is the interval between the cultivation of $R$. solani-susceptible sugar beet cultivars in the crop rotation (40). Root and crown rot is a region-specific problem in Central Europe, where sugar beet is often cultivated in rotation with maize. However, the influence of maize on the disease severity of $R$. solani in sugar beet has not been investigated until now.

Disease occurrence can additionally be varied by biological and physical soil properties which are influenced by tillage operations. Negative effects of soil compaction on Rhizoctonia disease severity were observed in sugar beet (5) as well as in bean (49). From an agronomic point of view, it is widely accepted that soil properties benefit from reduced tillage (12). However, Rovira (38) and Paulitz (34) detected a higher infestation level of $R$. solani after reduced tillage compared with plowing in cereals but, in potato and soybean, these negative effects were not confirmed (46). The effect of different tillage operations in relation to the severity of $R$. solani in sugar beet has not been investigated and reported to date.

These relationships led to the following questions. Does maize as precrop exert an influence on disease severity in sugar beet and does crop rotation and soil tillage have any relevance to the resistance of the sugar beet cultivar? This study attempts to demonstrate the influence of cultivar, crop rotation, and soil tillage on the severity of 
the disease. Therefore, a series of threefactorial field trials considering the aspects sugar beet cultivar, crop rotation, and soil tillage was established in a systematic approach. In these field trials, the contribution of these factors and the best combination of factors for reducing disease occurrence and leading to the highest yield under fields with natural infestation were investigated.

\section{MATERIALS AND METHODS}

Study sites. The field trials were carried out at four locations in Lower Bavaria in the neighborhood of Regensburg in the south of Germany (luvisol soil type; $8.9^{\circ} \mathrm{C}$ average temperature; approximately 800 $\mathrm{mm}$ rainfall in 2001 to 2005). The locations chosen for the experiments were naturally infested with $R$. solani AG 22IIIB, with an infestation level of 5 to $20 \%$ diseased beet plants in previous years. At the beginning of the trial, AG 2-2IIIB was isolated and identified at all locations from infected sugar beet. At two locations (environment $\mathrm{A}$ and $\mathrm{B}$ ), the field trial was started in 2001 and, at two further, locations (environment $\mathrm{C}$ and D), in 2002. All agricultural operations were carried out by the collaborating farmers in relation to typical regional guidelines. No fungicides against leaf pathogens (e.g., Cercospora beticola) were applied in sugar beet crops to exclude potential side effects on $R$. solani.

Experimental set up. In order to homogenize the $R$. solani inoculum level at each field and to minimize disease patches, sugar beet roots, severely infected with $R$. solani, were harvested from the respective field, cut into small pieces, and spread evenly on the soil surface at a density of approximately $1.5 \mathrm{~kg} / \mathrm{m}^{2}$ before plowing at the beginning of the trial with a manure distributor. At each site, the factors sugar beet cultivar, crop rotation, and, within each crop rotation, four cultivation methods were varied. Two cultivars (German identification numbers ZR 912 [susceptible] and 1164 [resistant]; 6) differing in susceptibility toward $R$. solani were grown in all crop rotations in the third year when data was collected. The three 3-year crop rotations, differing in the proportion of maize, were (i) maize-maize-sugar beet, (ii) maize-wheat-sugar beet, and (iii) wheat-oat-sugar beet, which were typical of crop rotations in southern Germany. All crops were cultivated following standard production practices and harvested at the end of the vegetation period by the collaborating farmers. The cultivation method, consisting of soil tillage and intercrop cultivation, was varied depending on the previous crop (Table 1). The tillage variation was crop specific and not generally differentiated as to mulching and plowing. Mulching was done with a cultivator at a depth of 25 to $30 \mathrm{~cm}$, plowing at the same depth with a turning plow. In the crop rotation maize-maize-sugar beet, only soil tillage was varied as cultivation method because intercrop cultivation after maize is not common. Cultivation methods one and two, in which a cultivator was used after the first year, had to be plowed in spring of the second year to minimize the risk of an infestation with European corn borer and to reduce the large amount of organic matter on the soil surface before sowing. In the other crop rotations besides soil tillage, mustard was cultivated as an intercrop before the summer annual crops of oat and sugar beet.

Table 1. Cultivation methods varied within the three crop rotations in this study

\begin{tabular}{lcll}
\hline Crop rotation & Cultivation method & After first crop & After second crop \\
\hline Maize/maize/sugar beet & 1 & Cultivator/plow & Cultivator \\
& 2 & Cultivator/plow & Plow \\
& 3 & Plow & Cultivator \\
Maize/wheat/sugar beet & 4 & Plow & Plow \\
& 1 & Cultivator & Plow/mustard \\
& 2 & Cultivator & Plow \\
Wheat/oat/sugar beet & 3 & Plow & Plow/mustard \\
& 4 & Plow & Cultivator/plow \\
& 1 & Plow/mustard & Plow/mustard \\
& 2 & Plow/mustard & Plow \\
& 3 & Plow & Plow/mustard \\
& 4 & Plow & Cultivator/plow \\
\hline
\end{tabular}

Table 2. Rating scale used for scoring Rhizoctonia root rot symptoms on sugar beet (8)

\begin{tabular}{lc}
\hline Description of symptoms & Disease class \\
\hline No visible lesions, plants apparently healthy & 1 \\
$<1 \%$ of the root surface with visible Rhizoctonia lesions & 2 \\
$>1-5 \%$ of the root surface with visible lesions & 3 \\
$>5-10 \%$ of the root surface with dry-rot canker & 4 \\
$>10-25 \%$ of the root surface with dry-rot canker & 5 \\
$>25-50 \%$ of the root surface with dry-rot canker & 6 \\
$>50-75 \%$ of the root surface with dry-rot canker & 7 \\
$>75 \%$ of the root surface with dry-rot canker & 8 \\
Plant dead and completely rotten & 9 \\
\hline
\end{tabular}

The study sites were split into smaller units in order to obtain the differentiated crop rotations and cultivation methods. The experiment was repeated twice in two complete blocks at each location. All crop rotations and cultivation methods were conducted by splitting each block by planting the different crops maize and wheat in the first year. Each of these maize and wheat plots were split again into four different cultivation methods. In the second year, the plots were split accordingly into subplots where maize, wheat, and oat were grown. Splitting the plots again, the differing cultivation methods were applied. In the third year, the area was divided perpendicularly to the main plots according to the crop rotations into 12 strips, where the two cultivars were grown. The 144 sugar beet plots at each location had dimensions of 3 by $6.75 \mathrm{~m}$, containing six rows of sugar beet plants, representing 24 treatments. Three inner rows were harvested for disease rating and trial processing (approximately 100 plants/plot). After removal of adhesive soil tare by washing, disease severity of each tap root was assessed on a 1-to-9 scale according to Büttner et al. (8), which is commonly used nationwide. The rating scale was based on nonlinear classification on percent diseased root surface with a precise distribution in the upper, less-diseased range (Table 2). The mean disease rating per plot was calculated based on the disease severity of the single taproots. Subsequently, root yield of each plot was determined. Beet brei samples from the whole plot were analyzed for contents of sucrose and melassigenic compounds (sodium, potassium, and $\alpha$-amino-N) following standard protocols (23) in an automatic beet laboratory system (Venema, Groningen, The Netherlands). White sugar yield was calculated following the standard equation for quality assessment in Germany $(4,27)$.

Statistical analysis. For statistical analysis (SAS version 9.1; SAS Institute, Cary, NC), the experiment was evaluated as a series of four split-plot designs. Although each two of the four locations are nested into the 2 years, they are considered as independent environments. A mixedmodel approach recognizing various error terms was set up. According to the randomization process, each randomization unit received a separate random effect (37). The fact that cultivation methods varied within the different crop rotations was reflected in a nested treatment model structure. The approximation method for denominator degrees of freedom for the tests of fixed effects was specified as by Kenward and Roger (24). In order to analyze the effect of cultivation methods within the crop rotation with more detail, the data set was reanalyzed, separating it by the different crop rotations. Depending on the results of the global $F$ test statistic, multiple comparisons were done following 
Tukey and Kramer. With the exception of interactions the significance level was $\alpha=$ 0.05 . In order to elucidate interactions significant at the level $P<\alpha=0.1$, effects were sliced into the single factors or factor combinations. However, results are only given for interactions not including location. Differences between treatments or treatment combinations with the lowest value for $P<|\mathrm{t}|$ were regarded as significant if the $F$ test statistics revealed significant differences between treatments even if the Tukey adjustment for multiple comparison did not reveal significance. As within the crop rotations, the cultivation methods in the 2 years before sugar beet can be considered as orthogonal (Table 1), and separate analyses were performed for the maize-maize-sugar beet and wheat-oatsugar beet rotations in order to analyze the effects of cultivation method in more detail. This analysis was not carried out for the maize-wheat-sugar beet crop rotation, because the effects of the cultivation methods within the 2 years are confounded with the effects of the crop grown in the respective year.

\section{RESULTS}

The analysis of variance (ANOVA) for the whole data set is given in Table 3 for disease severity and white sugar yield. Most of the significant effects on white sugar yield correspond to the effects on disease severity. For both parameters, significant effects of cultivar, environment, and the interactions of environmentcultivar, cultivar-crop rotation, and environment-cultivar-crop rotation were observed. Additionally, the effect of crop rotation was significant for white sugar yield. Both disease severity and white sugar yield were significantly influenced by the environment as a combination of location and year (Fig. 1). Disease rating ranged between 2.5 (location A) and 3.2 (location C). White sugar yield was significantly higher in locations $\mathrm{A}$ and $\mathrm{B}$ compared with $\mathrm{C}$ and $\mathrm{D}$. No general trend between disease severity and white sugar yield was detected.

The effect of the cultivar on disease severity is shown in Figure 2. The resistant cultivar displayed a lower infestation level than the susceptible one. Across crop rotation, disease severity of the susceptible cultivar ranged from 3.1 to 3.9 in contrast to the resistant cultivar, which ranged from 1.9 to 2.1. Furthermore, the significant interaction of sugar beet cultivar and crop rotation was illustrated by the differences in disease severity of about 2.0 points on the rating scale between the cultivars in the maize-maize rotation compared with 1.5 in the wheat-oat rotation.

White sugar yield was significantly influenced by sugar beet cultivar. Across rotations, the resistant cultivar gained a yield between 13.0 to 13.9 t/ha in contrast to 10.9 to $12.7 \mathrm{t} / \mathrm{ha}$ for the susceptible
Table 3. Analysis of variance for effects of location, sugar beet cultivar, crop rotation, and cultivation method nested within crop rotation on disease severity (1 to 9) of Rhizoctonia solani and white sugar yield of sugar beet

\begin{tabular}{|c|c|c|c|c|}
\hline \multirow[b]{2}{*}{ Effect } & \multicolumn{2}{|c|}{ Disease severity } & \multicolumn{2}{|c|}{ White sugar yield } \\
\hline & $F$ & $P^{a}$ & $F$ & $P^{\mathbf{a}}$ \\
\hline Sugar beet cultivar & 387.03 & $* * *$ & 133.66 & $* * *$ \\
\hline Crop rotation & 3.21 & $(*)$ & 7.38 & $* *$ \\
\hline Cultivation method (crop rotation) & 0.96 & n.s. & 2.07 & $(*)$ \\
\hline Environment & 3.36 & $*$ & 61.27 & $* * *$ \\
\hline Environment-cultivar & 31.57 & $* * *$ & 9.78 & $* *$ \\
\hline Environment-crop rotation & 1.41 & n.s. & 1.17 & n.s. \\
\hline Cultivar-crop rotation & 15.74 & $* * *$ & 16.63 & $* * *$ \\
\hline Environment-cultivar-crop rotation & 6.07 & $* * *$ & 4.68 & $* * *$ \\
\hline Cultivar-cultivation method (crop rotation) & 2.12 & $*$ & 1.71 & $(*)$ \\
\hline Environment-cultivation method (crop rotation) & 0.74 & n.s. & 1.05 & n.s. \\
\hline Environment-cultivar-cultivation method (crop rotation) & 1.12 & n.s. & 1.59 & $*$ \\
\hline Block (environment) & 0.39 & n.s. & 0.20 & n.s. \\
\hline
\end{tabular}

a Significance: $* * *, * *$, and $*=P<0.001,0.01$, and 0.05 , respectively; $(*)=P<0.1$; and n.s. $=$ not significant.

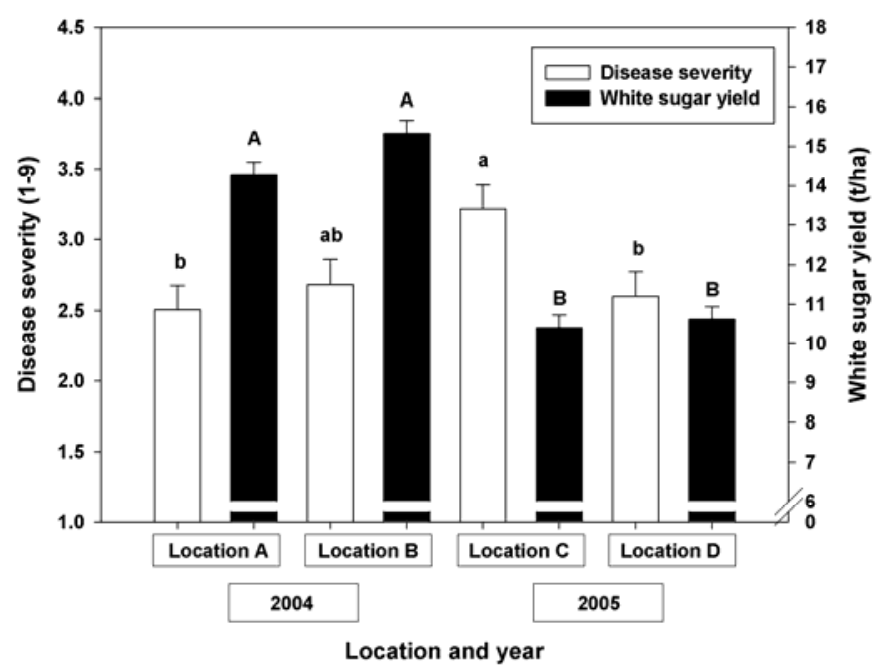

Fig. 1. Effect of location and year on disease severity of Rhizoctonia solani and on white sugar yield in sugar beet. Disease severity was assessed by visual rating $(1=$ healthy to $9=$ dead sugar beet). Treatment lsmeans with same letters are not significantly different at $P<0.05$ according to Tukey test. Error bars indicate standard error.

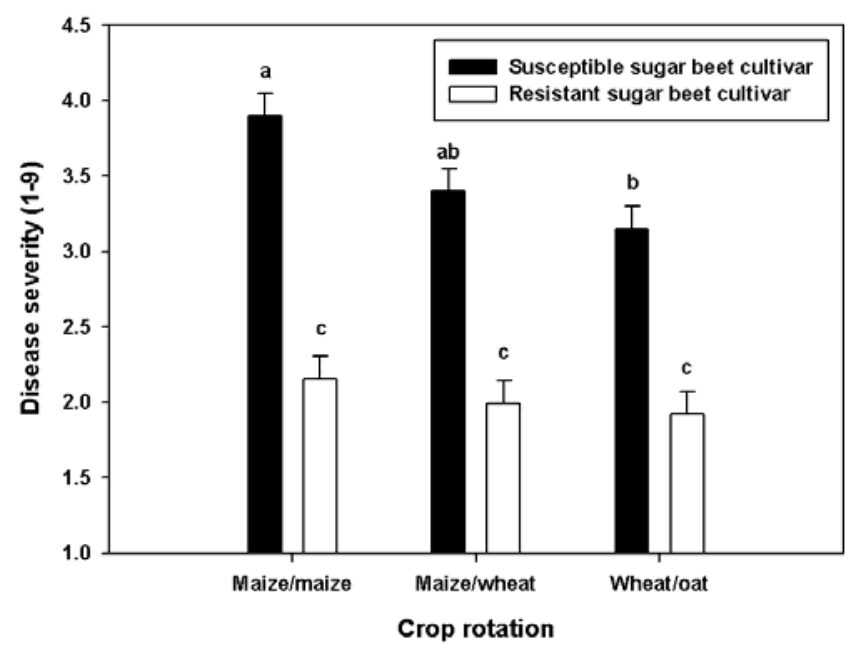

Fig. 2. Effect of crop rotation and sugar beet cultivar on disease severity of Rhizoctonia solani in sugar beet. Disease severity was assessed by visual rating $(1=$ healthy to $9=$ dead sugar beet $)$. Mean of two locations in 2004 and two locations in 2005. Treatment lsmeans with same letters are not significantly different at $P<0.05$ according to Tukey test. Error bars indicate standard error. 
cultivar (Fig. 3). Furthermore, crop rotation showed a significant effect on the white sugar yield. White sugar yield was lowest in the rotation maize-maize and highest in the crop rotation with wheat and oat. Beet plants grown after maize-wheat reached an intermediate white sugar yield. As for disease severity, a significant interaction of crop rotation and sugar beet cultivar was observed for white sugar yield, showing a bigger difference between susceptible and resistant cultivar in the maizemaize rotation than in the wheat-oat rota- tion and a significant effect only in the susceptible cultivar (Fig. 3).

The effect of the cultivation method within the crop rotations on the two parameters was less consistent. Cultivation method within the crop rotation did not influence disease severity but the white sugar yield did $(P<0.1$, Table 3$)$. The effect of cultivation method on the performance of sugar beet became more evident when a separate, more detailed analysis for the three crop rotations was performed (Table 4). No significant effect

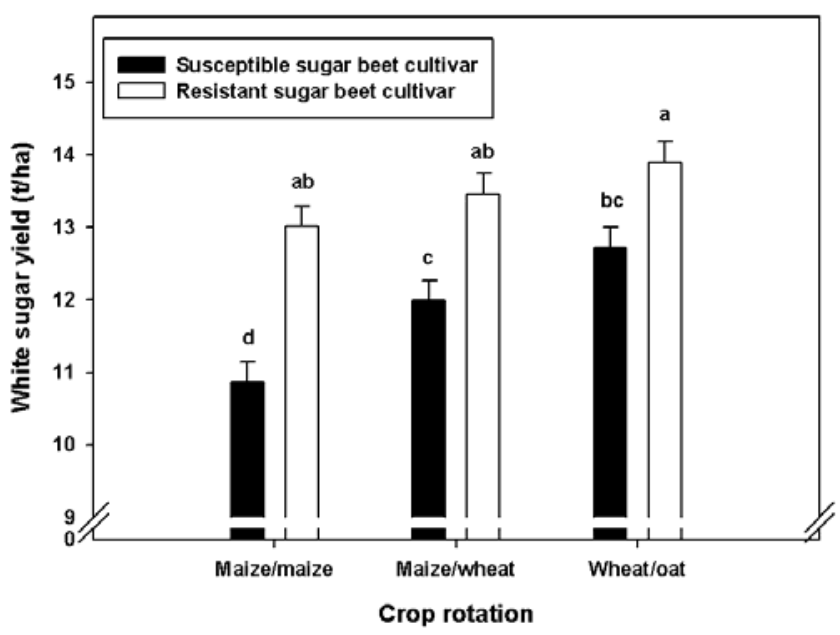

Fig. 3. Effect of crop rotation and sugar beet cultivar on the white sugar yield in sugar beet. Mean of two locations in 2004 and two locations in 2005. Treatment lsmeans with same letters are not significantly different at $P<0.05$ according to Tukey test. Error bars indicate standard error.

Table 4. Analysis of variance for effects of location, sugar beet cultivar, and cultivation method separated by crop rotation on disease severity (1 to 9) of Rhizoctonia solani and white sugar yield of sugar beet

\begin{tabular}{|c|c|c|c|c|}
\hline \multirow[b]{2}{*}{ Crop rotation, effect } & \multicolumn{2}{|c|}{ Disease severity } & \multicolumn{2}{|c|}{ White sugar yield } \\
\hline & $\boldsymbol{F}$ & $P^{\mathbf{a}}$ & $\boldsymbol{F}$ & $P^{\mathbf{a}}$ \\
\hline \multicolumn{5}{|l|}{ Maize/maize/sugar beet } \\
\hline Environment & 21.94 & $* *$ & 51.86 & ** \\
\hline Cultivar & 266.00 & $* * *$ & 138.50 & $* * *$ \\
\hline Cultivation method & 3.79 & * & 6.72 & $* *$ \\
\hline Environment-cultivar & 24.59 & $* * *$ & 12.01 & $* *$ \\
\hline Environment-cultivation method & 1.12 & n.s. & 3.24 & $*$ \\
\hline Cultivar-cultivation method & 1.41 & n.s. & 2.74 & $(*)$ \\
\hline Cultivar-environment-cultivation method & 0.27 & n.s. & 1.48 & n.s. \\
\hline Block (environment) & 2.30 & n.s. & 0.65 & n.s. \\
\hline \multicolumn{5}{|l|}{ Maize/wheat/sugar beet } \\
\hline Environment & 0.60 & n.s. & 13.35 & * \\
\hline Cultivar & 106.75 & $* * *$ & 22.11 & $* *$ \\
\hline Cultivation method & 0.44 & n.s. & 0.94 & n.s. \\
\hline Environment-cultivar & 6.75 & $*$ & 2.19 & n.s. \\
\hline Environment-cultivation method & 1.85 & n.s. & 1.12 & n.s. \\
\hline Cultivar-cultivation method & 0.34 & n.s. & 0.74 & n.s. \\
\hline Cultivar-environment-cultivation method & 0.38 & n.s. & 0.41 & n.s. \\
\hline Block (environment) & 0.04 & n.s. & 0.08 & n.s. \\
\hline \multicolumn{5}{|l|}{ Wheat/oat/sugar beet } \\
\hline Environment & 0.51 & n.s. & 67.06 & $* * *$ \\
\hline Cultivar & 56.85 & $* * *$ & 15.22 & $* *$ \\
\hline Cultivation method & 5.31 & $* *$ & 5.59 & ** \\
\hline Environment-cultivar & 5.42 & * & 0.43 & n.s. \\
\hline Environment-cultivation method & 3.20 & $*$ & 1.99 & $(*)$ \\
\hline Cultivar-cultivation method & 4.50 & ** & 1.56 & n.s. \\
\hline Cultivar-environment-cultivation method & 1.29 & n.s. & 1.12 & n.s. \\
\hline Block (environment) & 1.79 & n.s. & 3.84 & $*$ \\
\hline
\end{tabular}

a Significance: $* * *, * *$, and $*=P<0.001,0.01$, and 0.05 , respectively; $(*)=P<0.1$; and n.s. $=$ not significant. of cultivation method was found on either disease severity or white sugar yield in the crop rotation maize-wheat-sugar beet whereas, in the two other crop rotations, the cultivation method significantly influenced both parameters. In the maizemaize-sugar beet rotation, cultivation methods 1 and 3 (cultivator use before sowing sugar beet; Table 1) resulted in higher disease severity ratings and lower white sugar yields compared with cultivation methods 2 and 4 (Figs. 4 and 5). Therefore, in this crop rotation, the cultivation method in the second year, directly before sugar beet, revealed significance $(P$ $<0.05$; ANOVA for orthogonal cultivation method not shown). Plowing compared with cultivator use directly before sugar beet (cultivation methods 1 and 3 compared with 2 and 4 ) reduced disease rating significantly by 0.46 rating points and correspondingly increased white sugar yield significantly by $1.2 \mathrm{t} / \mathrm{ha}$. Within the wheat-oat-sugar beet rotation, cultivation methods 1 and 2 (mustard as intercrop before oat) resulted in lower disease severity and a higher white sugar yield compared with cultivation methods 3 and 4 . The cultivation of mustard before oat reduced disease severity significantly from 2.7 to 2.1 and increased white sugar yield with $0.46 \mathrm{t} / \mathrm{ha}$, whereas the cultivation of mustard before sugar beet had no significant influence (ANOVA for orthogonal cultivation method not shown).

\section{DISCUSSION}

The aim of this study was to investigate the influence of maize as precrop in sugar beet rotations on the severity of $R$. solani infestation and to evaluate the potential of crop rotation and cultivation methods in relation to resistant cultivars to control $R$. solani in European sugar beet production.

The inoculation treatment equalized the inoculum potential on each location because disease occurrence was uniform within treatments. However, existing variations of infestation levels between the environments remained (Fig. 1). Moreover, different farmers were responsible for the agronomic measures within the frame of regional guidelines, additionally increasing the variability. For white sugar yield, a clear effect of the year was observed. In our investigations, the influence of the location had a bigger influence, demonstrated by the larger difference between the locations than between the years. This is in agreement with the results of Wolf and Märländer (52), who found that location in contrast to year had the major effect on white sugar yield in sugar beet. Hence, the locations were analyzed as independent environments and, furthermore, significant effects of the locations on white sugar yield were expected. However, the variation between the environments and the resulting interactions cannot be explained in detail. 
As anticipated, all three integrated control measurements had an effect on Rhizoctonia disease severity and on white sugar yield, with the sugar beet cultivar having the strongest effect on these parameters. Under the infection pressure which was built up in the present study, plants of the resistant cultivar had lower disease levels, independent of the precrop. In the resistant cultivar, the mean disease severity was 2.0 in contrast to 3.5 in the susceptible cultivar. Ruppel and Hecker (42) found a high level of resistance against $R$. solani in the sugar beet breeding lines in U.S. trials. This breeding material was introduced into the European cultivars, so that the lower disease incidence in the resistant cultivars could be expected (7). In the present study, the higher white sugar yield of the resistant cultivar of $13.5 \mathrm{t} / \mathrm{ha}$ compared with $11.9 \mathrm{t} / \mathrm{ha}$ in the susceptible cultivar produces evidence that a high sugar yield can be realized under natural infection pressure with resistant cultivars. Although the resistant sugar beet cultivar was hardly affected by $R$. solani (reflected by the low disease rates), independent of hosts or nonhosts in the rotation, this does not allow the conclusion that, in a longterm perspective, the cultivation of resistant cultivars will be sufficient to control the disease.

In addition to cultivar, crop rotation is another factor influencing disease severity and white sugar yield. We found higher disease severity and a decreased white sugar yield with increasing proportion of maize as host plants in the crop rotation. The effect on disease severity is in accordance with previous studies (45), which demonstrated that shorter crop rotations induced an increase of $R$. solani in sugar beet. The impact of a susceptible precrop, even though not proved for maize and AG 2-2IIIB, has been demonstrated in several other studies. An increase in the proportion of host plants increased disease severity and decreased sugar yield (14,51). Ruppel (40) found that disease reduction was influenced more by the length of the beet free period than by the precrop. It is expected that, if a higher proportion of host plants are cultivated in the crop rotation, the inoculum potential will increase. On the other hand, we anticipate that the inoculum potential will decrease with time in crop rotations with a smaller percentage of host plants. Herr (20) found different infestation levels of $R$. solani after different rotation crops. It is generally accepted that the survival and concentration of $R$. solani in the soil is dependant on organic debris particles (33); however, suppressive soils, antagonists, and soil mycoflora also control the survival of the pathogen $(22,28,50)$. These factors can be influenced by different crop residues.

No clear effect of the different cultivation methods within crop rotations was observed in the present study (Table 3).
However, the effect of the specific cultivation method turned out to be important in the susceptible cultivar and not in all crop rotations (Table 4). This is explained by the different soil tillage methods in combination with the intercrop cultivation in some crop rotations. In the crop rotation maize-maize-sugar beet, only an alteration of plowing and mulching was carried out without growing an intercrop, resulting in bigger differences between the plowing and reduced cultivation methods than in the other crop rotations. In agreement with the studies of Rovira (38) and Paulitz (34) on $R$. solani in cereals, we found a higher infestation level and a lower white sugar yield after the reduced soil tillage treatments 1 and 3 in comparison with treatments 2 and 4 applying plowing before cultivation of sugar beet. $R$. solani survives in higher percentages in upper than in deeper soil layers $(19,41)$ and this might

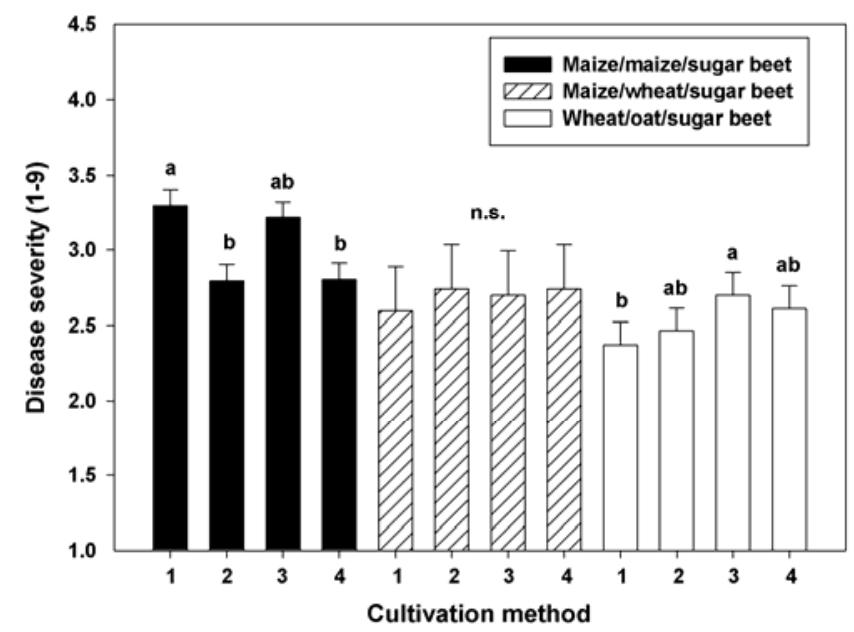

Fig. 4. Effect of cultivation method within crop rotation on disease severity in sugar beet. Disease severity was assessed by visual rating $(1=$ healthy to $9=$ dead sugar beet $)$. Mean of two locations in 2004 and two locations in 2005. Treatment lsmeans with same letters are not significantly different at $P<0.05$ according to Tukey test for analysis of variance separated by crop rotation. Error bars indicate standard error.

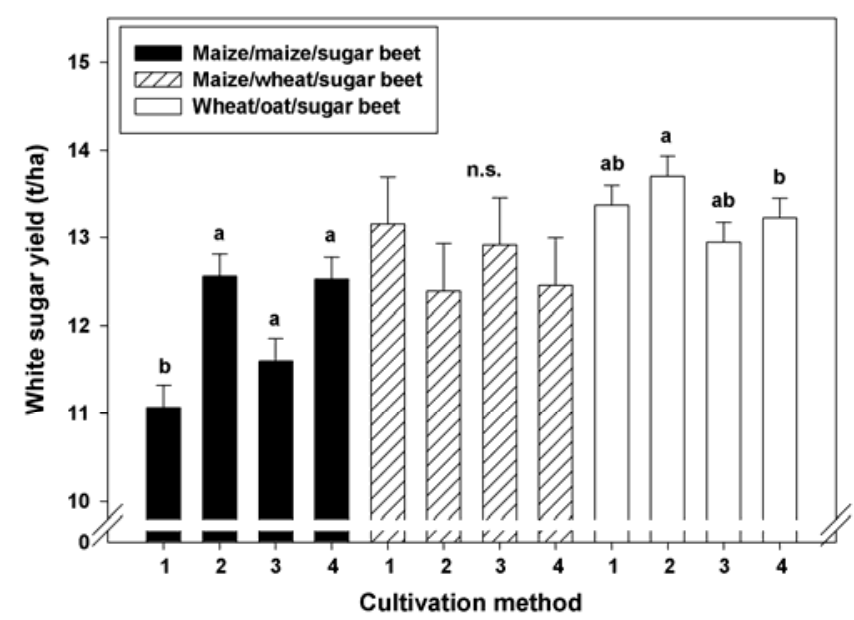

Fig. 5. Effect of crop rotation and cultivation method within crop rotations on white sugar yield in sugar beet. Mean of two locations in 2004 and two locations in 2005. Treatment lsmeans with same letters are not significantly different at $P<0.05$ according to Tukey test for analysis of variance separated by crop rotation. Error bars indicate standard error. explain the observed results. The additional analysis for orthogonal cultivation potential even if maize is grown directly before sugar beet. Therefore, if maize is grown in high proportion in the crop rotation for economic reasons, plowing before cultivation of sugar beet is strongly recing undered to estimate the effect of plow-

In contrast to the effect of cultivation method within the maize-maize rotation, the cultivation method in the wheat-oatsugar beet rotation of the first year proved tard was grown as intercrop in addition to varied soil tillage. After the first year of cereals cultivation, the introduction of an intercrop (soil tillage treatment 1 and 2) possibly decreased inoculum potential and, second-year plowing can reace inoculum ommended. However, long-term studies 
therefore, increased performance of sugar beet. In other studies, positive effects of intercrop cultivation and soil incorporation of their residues on disease severity of $R$. solani have been described (29). Mulching instead of plowing may have imposed a negative effect on sugar beet as it was described by Håkansson et al. (17). The positive effects of the intercrops mentioned superimpose the negative effects of reduced soil tillage treatments under diseased conditions in these crop rotations and may have led to the observed effect in the present study. The cultivation of an intercrop after the second year (soil tillage treatments 1 and 3 ) had no additional positive effect.

Sugar beet cultivar had the highest impact on disease severity, with a difference between susceptible and resistant cultivar of 1.5 rating points. Crop rotation and cultivation method had a lower impact on disease severity, with a maximum differences of 0.5. In contrast, the main effects of the three tested factors sugar beet cultivar, crop rotation, and cultivation method within crop rotation on white sugar yield were comparable. This is indicated by the maximum differences between the highest and the lowest yield of 1.6, 1.4, and 1.5 $\mathrm{t} / \mathrm{ha}$, respectively. However, these main effects showed strong interactions with the other factors and have to be further studied in detail. A strong effect of the interaction of cultivar and crop rotation is observed by more pronounced differences in disease severity and white sugar yield between resistant and susceptible cultivar in the maize-maize-sugar beet rotation than in the wheat-oat-sugar beet rotation (Figs. 2 and 3). In the wheat-oat rotation, white sugar yield of the susceptible cultivar was comparable with the resistant one in the maize-maize rotation, although the susceptible cultivar had a higher disease severity (disease rating 3.2 compared with 2.2 , respectively). This might be explained by the general positive wheat-oat crop rotation effect on white sugar yield. Consequently, more diseased plant material of stronger diseased plants (corresponding to higher disease rating) will remain in the soil and probably further increase the disease severity in future sugar beet crops. Therefore, we can conclude that, under these conditions, even an optimal crop rotation cannot cope with the disease and that cultivation of a resistant cultivar is a prerequisite for sustainable sugar beet production. Although we were able to show the effect of maize on sugar beet in the rotation, it is yet unknown whether $R$. solani-infested maize plant residues will increase the inoculum potential in the soil. In former studies, no increase of the inoculum potential by the cultivation of maize could be observed (20). Sugar beet seems to influence the inoculum potential in soil much more than other plants. This has to be examined in future experiments.
Differences in susceptibility to $R$. solani between different maize cultivars have been described by Pfähler and Petersen (36). Up to now, it is unknown whether a coexistence of sugar beet and maize cultivars that show a reduced propagation of $R$. solani in the same crop rotation under Rhizoctonia spp. infestation is possible. In the experiment described here, we studied short-term effects of sugar beet cultivar and crop rotation on disease severity in sugar beet. Methods for a reliable determination of inoculum potential on a large scale are not yet available and disease occurrence is strongly influenced by climatic conditions; therefore, implementation and forecasting of disease occurrence is impossible. Therefore, we can only estimate retrospectively from the disease severity of the susceptible cultivar to the estimated inoculum potential in the soil. Further crop rotation experiments and the development of reliable $R$. solani quantification methods are necessary to answer these open questions.

Previous studies $(13,47)$ have isolated $R$. solani AG 2-2IIIB and AG 2 from maize and used the isolate for reinfection to prove pathogenicity. With the data obtained in this study, we can show for the first time that, under European climate conditions, the replacement of Rhizoctonia spp. nonhosts in the rotation with maize exerts a strong influence on disease severity and yield in subsequently grown sugar beet. In addition, the extensive field trials give strong evidence that cultivation of $R$. solani-resistant sugar beet cultivars can enable an adequate yield even at increased disease conditions above the natural level and in rotation with other host plants. However, it can be stated from the results obtained here that none of the tested control measures alone will be sufficient to solve the problems in $R$. solani-infested areas in Europe. Our results support the conclusion of Herr (21) that the best integrated control management includes good cultivation practices and resistant germplasm. However, it cannot be foreseen whether all measures integrated will be sufficient to reduce the inoculum potential in infested soils significantly if once established.

Taken together, adapted crop rotation and the cultivation of resistant sugar beet cultivars are suitable means of reducing the inoculum potential and disease occurrence under European conditions. It remains uncertain whether curing of a location from the disease by these integrated measurements is at all possible.

\section{ACKNOWLEDGMENTS}

We thank the technical staff of the Arbeitsgemeinschaft Regensburg and the Institute of Sugar Beet Research for their excellent job in the field; the collaborating farmers for their good cooperation; A. Büchse for statistical advice; S. Dunker, C. Kenter, S. Kluth, and two anonymous reviewers for their valuable comments on the manuscript; and $\mathrm{R}$. Pilot for help with English style and grammar.
LITERATURE CITED

1. Allen, M. F., Boosalis, M. G., Kerr, E. D., Muldoon, A. E., and Larsen, H. J. 1985. Population dynamics of sugar beets, Rhizoctonia solani, and Laetisaria arvalis: Response of a host, plant pathogen, and hyperparasite to perturbation in the field. Appl. and Environ. Microbiol. 50:1123-1127.

2. Ayala Garcia, J., Büttner, G., Guitiérrez, H., Heijbroek, W., Ioannides, P., Nihlgaard, M. Richard Molard, M., Panella, L., Rossi, V., Rösner, H., Schneider, J. H. M., and Wouters, A. 2001. Integrated control of Rhizoctonia root rot-first results of an I.I.R.B. trial series. Pages 397-400 in: Proc. 64th IIRB Congr.

3. Bruhns, M., Lemmes, R., and Schick, R., Jr. 2004. Verarbeitungseigenschaften von Rhizoctonia-geschädigten Rüben. Zuckerindustrie 129:105-111.

4. Buchholz, K., Märländer, B., Puke, H. Glattkowski, H., and Thielecke, K. 1995. Neubewertung des technischen Wertes von Zuckerrüben. Zuckerindustrie 120:113-121.

5. Buddemeyer, J., and Märländer, B. 2004 Integrierte Kontrolle der Späten Rübenfäule (Rhizoctonia solani Kühn) in ZuckerrübenEinfluss von Anbaumaßnahmen und Fruchtfolgegestaltung sowie Sortenwahl unter besonderer Berücksichtigung des Maises. Zuckerindustrie 129:676-686.

6. Bundessortenamt. 2007. Beschreibende Sortenliste 2007. Getreide, Mais, Ölfrüchte, Leguminosen (großkörnig), Hackfrüchte (außer Kartoffel). Deutscher Landwirtschaftsverlag.

7. Büttner, G., Führer Ithurrart, M. E., and Buddemeyer, J. 2002. Späte Rübenfäule Rhizoctonia solani-Verbreitung, wirtschaftliche $\mathrm{Be}-$ deutung und integrierte Bekämpfungskonzepte. Zuckerindustrie 127:856-866.

8. Büttner, G., Pfähler, B., and Märländer, B. 2004. Greenhouse and field techniques for testing sugar beet for resistance to Rhizoctonia root and crown rot. Plant Breed. 123:158-166.

9. Carling, D. E. 1996. Grouping in Rhizoctonia solani by hyphal anastomosis reaction. Pages 35-48 in: Rhizoctonia Species: Taxonomy, Molecular Biology, Ecology, Pathology and Disease Control. B. Sneh, S. Jabaji-Hare, S. Neate, and G. Dijst, eds. Kluwer Academic Publishers, Dordrecht, The Netherlands.

10. Carling, D. E., Kuninaga, S., and Brainard, K. A. 2002. Hyphal anastomosis reactions, rDNA-internal transcribed spacers sequences, and virulence levels among subsets of Rhizoctonia solani anastomosis group-2 (AG 2) and AG-BI. Phytopathology 92:43-50.

11. Engelkes, C. A., and Windels, C. E. 1996. Susceptibility of sugar beet and beans to Rhizoctonia solani AG-2-2 IIIB and AG-2-2 IV. Plant Dis. 80:1413-1417.

12. Frede, H. G., Beisecker, R., and Gäth, S. 1994 Long-term impacts of tillage on soil ecosystems. Z. Pflanzenernähr. Bodenk. 157:197203.

13. Führer Ithurrart, M. E., Büttner, G., and Petersen, J. 2004. Rhizoctonia root rot in sugar beet (Beta vulgaris spp. altissima)-epidemiological aspects in relation to maize (Zea mays) as a host plant. J. Plant Dis. Prot. 111:302-312.

14. Garressus, S., Muchembled, C., Camporota, P., and Bazin, J. 1995. Le rhizoctone brun de la betterave sucriere etudes au laboratoire et au champ, recherches de methods de lutte. Pages 279-288 in: Proc. 58th IIRB Congr.

15. Gaskill, J. O. 1968. Breeding for Rhizoctonia resistance in sugarbeet. J. Am. Soc. Sugar Beet Technol. 15:107-119.

16. Gilligan, C. A., Simons, S. A., and Hide, G. A 1996. Inoculum density and spatial pattern of Rhizoctonia solani in field plots of Solanum tuberosum: effects of cropping frequency. Plant Pathol. 45:232-244.

17. Håkansson, I., Henriksson, L, and Blomquist, J.E. 2006. Soil tillage and crop establishment 
Pages 114-133 in: Sugar beet. A. P. Draycott. Blackwell Publishing, Oxford, UK.

18. Hecker, R. J., and Ruppel, E. G. 1975. Inheritance of resistance to Rhizoctonia root rot sugarbeet. Crop Sci. 15:487-490.

19. Herr, L. J. 1976. In field survival of Rhizoctonia solani in soil and diseased sugarbeets. Can. J. Microbiol. 22:983-988.

20. Herr, L. J. 1987. Population of Rhizoctonia solani in soil under crops in rotation with sugar beet. Ann. Appl. Biol. 110:17-24.

21. Herr, L. J. 1996. Sugar beet diseases incited by Rhizoctonia spp. Pages 341-350 in: Rhizoctonia Species: Taxonomy, Molecular Biology, Ecology, Pathology and Disease control. B. Sneh, S. Jabaji-Hare, S. Neate, and G. Dijst, eds. Kluwer Academic Publishers, Dordrecht, The Netherlands.

22. Homma, Y. 1996. Antibiotics and siderophore producing bacteria. Pages 445-453 in: Rhizoctonia Species: Taxonomy, Molecular Biology, Ecology, Pathology and Disease Control. B. Sneh, S. Jabaji-Hare, S. Neate, and G. Dijst, eds. Kluwer Academic Publishers, Dordrecht, The Netherlands.

23. International Commission for Uniform Methods of Sugar Analysis. 2007. Methods Book 2007. Verlag Dr. Albert Bartens KG, Berlin.

24. Kenward, M. G., and Roger, J. H. 1997. Small sample inference for fixed effects from restricted maximum likelihood. Biometrics 53:983-997.

25. Larkin, R. P., and Honeycutt, C. W. 2006. Effects of different 3-year cropping systems on soil microbial communities and Rhizoctonia disease of potato. Phytopathology 96:68-79.

26. Liu, Z., and Sinclair, J. B. 1991. Isolates of Rhizoctonia solani anastomosis group 2-2 pathogenic to soybean. Plant Dis. 75:682-687.

27. Märländer, B., Hoffmann, C., Koch, H. K., Ladewig, E., Merkes, R., Petersen, J., and Stockfisch, N. 2003. Environmental situation and yield performance of the sugar beet crop in Germany: heading for sustainable development. J. Agron. Crop Sci. 189:201-226.

28. Mazzola, M. 2004. Assessment and management of soil microbial community structure for disease suppression. Annu. Rev. Phytopathol. 42:35:59.

29. Mazzola, M., Brown, J., Izzo, A. D., and
Cohen, M. F. 2007. Mechanism of action and efficacy of seed meal-induced pathogen suppression differ in a Brassica species and timedependent manner. Phytopathology 97:454460.

30. Nelson, B., Helms, T., Christianson, T., and Kural, I. 1996. Characterization and pathogenicity of Rhizoctonia from soybeans. Plant Dis. 80:74-80.

31. Ogoshi, A. 1987. Ecology and pathogenicity of anastomosis and intraspecific groups of Rhizoctonia solani Kühn. Annu. Rev. Phytopathol. 25:125-143.

32. Panella, L. 2005. Root rots. Pages 95-100 in: Genetics and Breeding of Sugar Beet. E. Biancardi, L. G. Campbell, G. N. Skaracis, and M. de Biaggi. Science Publishers.

33. Papavizas, G. C. 1968. Survival of rootinfecting fungi in soil. VIII. Distribution of Rhizoctonia solani in various physical fractions of naturally and artificially infested soils. Phytopathology 58:746-751.

34. Paulitz, T. C. 2006. Low input no-till cereal production in the pacific northwest of the U.S.: the challenges of root diseases. Eur. J. Plant Pathol. 115:271-281.

35. Peters, R. D., Sturz, A. V., Carter, M. R., and Sanderson, J. B. 2003. Developing diseasesuppressive soils through crop rotation and tillage management practices. Soil Tillage Res. 72:181-192.

36. Pfähler, B., and Petersen, P. 2004. Rapid greenhouse screening of maize for resistance to Rhizoctonia solani AG 2-2IIIB. J. Plant Dis. Prot. 111:292-301.

37. Piepho, H. P., Büchse, A., and Emrich, K. 2003. A hitchhiker's guide to mixed models for randomized experiments. J. Agron. Crop Sci. 189:310:322.

38. Rovira, A. D. 1986. Influence of crop rotation on Rhizoctonia bare batch of wheat. Phytopathology 76:669-673.

39. Ruppel, E. G. 1973. Histopathology of resistant and susceptible sugar beet roots inoculated with Rhizoctonia solani. Phytopathology 63:23-126.

40. Ruppel, E. G. 1985. Susceptibility of rotation crops to a root rot isolate of Rhizoctonia solani from sugar beet and survival of the pathogen in crop residues. Plant Dis. 69:871-873.
41. Ruppel, E. G. 1991. Survival of Rhizoctonia solani in fallow field soil and buried sugarbeet roots in three depths. J. Sugar Beet Res. 28:141-153

42. Ruppel, E. G., and Hecker, R. J. 1994. Rhizoctonia root rot on sugarbeet cultivars having varied degrees of resistance. J. Sugar Beet Res. 31:135-143

43. Rush, C. M., and Winter, S. R. 1990. Influence of previous crops on Rhizoctonia root and crown rot of sugar beet. Plant Dis. 74:421-425.

44. Schillinger, W. F., and Paulitz, T. C. 2006 Reduction of Rhizoctonia bare patch in wheat with barley rotations. Plant Dis. 90:302-306.

45. Schuster, M. L., and Harris, L. 1960. Incidence of Rhizoctonia crown rot on sugar beet in irrigated crop rotation. J. Am. Soc. Sugar Beet Technol. 11:128-136.

46. Sturz, A. V., Carter, M. R., and Johnston, H. W 1997. A review of plant disease, pathogen interactions and microbial antagonism under conservation tillage in temperate humid agriculture. Soil Tillage Res. 41:169-189.

47. Sumner, D. R., and Bell, D. K. 1982. Root diseases induced by Rhizoctonia solani and Rhizoctonia zeae. Phytopathology 72:86-91.

48. Sumner, D. R., and Bell, D. K. 1986. Influence of crop rotations on severity of crown and brace root caused in corn by Rhizoctonia solani. Phytopathology 76:248-252.

49. Tu, J. C. and Tan, C. S. 1991. Effect of soil compaction on growth, yield and root rots of white beans in clay loam and sandy loam soil. Soil Biol. Biochem. 23:233-238.

50. Van den Boogert, P. H. J. F. 1996. Mycoparasitism and biocontrol. Pages 485-493 in Rhizoctonia Species: Taxonomy, Molecular Biology, Ecology, Pathology and Disease Control. B. Sneh, S. Jabaji-Hare, S. Neate, and G. Dijst, eds. Kluwer Academic Publishers, Dordrecht, The Netherlands.

51. Windels, C. E., and Brantner, J. R. 2004 Previous crop influences Rhizoctonia on sugarbeet. Sugarbeet Res. Ext. Rep. 35:227231.

52. Wolf, I., and Märländer, B. 1994. Bedeutung der Sorte für die Leistung von Zuckerrüben in Abhängigkeit von Standort, Region und Jahr. Zuckerindustrie 119:671-678 